\title{
METAMORFOSIS GOTONG ROYONG DALAM PANDANGAN KONSTRUKSI SOSIAL ${ }^{1}$
}

\author{
Oleh : \\ Maulana Irfan ${ }^{2}$
}

Email : maulana.irfan@unpad.ac.id

\begin{abstract}
ABSTRAK
Budaya gotong royong ini sesungguhnya bukan hal baru dalam peradaban manusia. Pada dasarnya manusia sesuai dengan fitrahnya merupakan makhluk sosial yang tidak biasa hidup sendiri melainkan membutuhkan pertolongan orang lain. Oleh sebab itu di dalam kehidupan masyarakat diperlukan adanya kerjasama dan sikap gotong royong dalam menyelesaikan segala permasalahan Ketika gotong royong menjadi penciri dari Kearifan Lokal bangsa Indonesia yang menunjukkan kohesi sosial dalam solidaritas sosial dan interaksi sosial, masihkah kegotongroyongan tersebut tumbuh dan berkembang di masa sekarang? Manakala arus globalisasi tidak terbendung lagi dan manakala masyarakat terkotak-kotak dalam sebuah komunitas sesuai keberminatan mereka.Proses metamorfosis gotong royong inilah yang menjadi fokus tulisan ini ketika memandang konsep gotong royong di tengah arus globalisasi dunia dalam bentuk sosial media dengan melihat sudut pandang teori konstruksi sosial.
\end{abstract}

\section{Kata Kunci : Gotong Royong, Perubahan Sosial, Konstruksi Sosial, Pekerjaan Sosial}

\section{PENDAHULUAN}

Indonesia kaya dengan keberagaman budaya. Indonesia dikenal oleh dunia karena masyarakat Indonesia memiliki sikap ramah, kekeluargaan dan gotong royong didalam kehidupan sehari-hari. Gotong royong seakan sudah mengakar menjadi penciri budaya bangsa Indonesia. Budaya gotong royong di Indonesia dapat dibuktikan dalam berbagai macam bentuk dan istilah yang berbeda sesuai dengan daerah masing-masing. Misalnya di pedesaan Jawa yang masih melakukan praktik tradisi gotong royong dalam pembangunan rumah, perkawinan dan kematian. Di Toraja, Sulawesi Selatan, mempraktikkan arisan tenaga, yaitu kegiatan semacam kerja bakti bergilir untuk menggarap sawah atau ladang milik warga lain. Suku Dayak melakukan hal yang sama yang disebut sa'aleant.

Budaya gotong royong ini sesungguhnya bukan hal baru dalam peradaban manusia. Kropotkin (2006) mengungkap :

Sosialitas dan kebutuhan gotong royong dan saling dukung merupakan bagian yang sangat melekat pada sifat manusia. Akibatnya, dalam masa kapan pun dalam sejarah, tak pernah kita lihat manusia tinggal dalam keluarga kecil terasing, saling kelahi

\footnotetext{
${ }^{1}$ Makalah ini disampaikan dalam Seminar Nasional Menuju Masyarakat Indonesia Sejahtera, Auditorium Fikom UNPAD. 22 Desember 2016

${ }^{2}$ Dosen pada Program Studi Kesejahteraan Sosial Fakultas IImu Sosial dan IImu Politik Universitas Padjadjaran
} 
demi tetap hidup. Hal yang sebaliknya dibuktikan oleh riset modern. (hal: 1)

Ini menunjukkan bahwa kehidupan manusia dalam masyarakat tidak terlepas dari adanya interaksi sosial antar sesamanya. Pada dasarnya manusia sesuai dengan fitrahnya merupakan makhluk sosial yang tidak biasa hidup sendiri melainkan membutuhkan pertolongan orang lain. Oleh sebab itu di dalam kehidupan masyarakat diperlukan adanya kerjasama dan sikap gotong royong dalam menyelesaikan segala permasalahan.

Selain itu, gotong royong adalah juga salah satu bentuk dari solidaritas sosial. Emile Durkheim yang di kutip oleh Robbert M.Z Lawang (1985:63) mengartikan solidaritas sosial sebagai berikut :

Solidaritas sosial adalah keadaan saling percaya antar anggota kelompok atau komunitas. Jika orang saling percaya mereka akan menjadi satu atau menjadi sahabat, menjadi saling menghormati, menjadi saling bertanggung jawab untuk saling membantu dalam memenuhi kebutuhan antar sesama.

Durkheim, membagi solidaritas menjadi dua yaitu solidaritas organik dan solidaritas mekanik, yang dimaksud dengan solidaritas organik adalah solidaritas yang didasarkan atas perbedaan-perbedaan, solidaritas ini muncul akibat timbulnya pembagian kerja yang makin besar, solidaritas ini didasarkan atas tingkat ketergantungan yang sangat tinggi. Sedangkan yang dimaksud dengan solidaritas mekanik adalah bahwa solidaritas ini didasarkan pada tingkat homogenitas yang tinggi dalam kepercayaan, sentimen dan sebagainya.

Ketika gotong royong menjadi penciri dari Kearifan Lokal bangsa Indonesia yang menunjukkan kohesi sosial dalam solidaritas sosial dan interaksi sosial, masihkah kegotongroyongan tersebut tumbuh dan berkembang di masa sekarang? Manakala arus globalisasi tidak terbendung lagi dan manakala masyarakat terkotak-kotak dalam sebuah komunitas sesuai keberminatan mereka. Bisa jadi ini adalah ironi atau pembuktian dari pernyataan yang disampaikan oleh Friedman (2005) bahwa The World Is Flat. Dalam tulisannya Friedman menjelaskan bahwa Globalisasi versi 3.0 dimulai tahun 2000, yang menyusutkan dunia dari ukuran kecil menjadi sangat kecil dan mendatarkan lapangan permainan. Era yang memungkinkan memberdayakan dan melibatkan individu serta kelompok kecil untuk dengan mudah menjadi global dengan sebutan "tatanan dunia datar" (flat world platform). Motor penggerak Globalisasi 3.0 adalah kekuatan baru yang ditemukan untuk bekerjasama dan bersaing secara individual dalam kancah global.

Salah satu penciri globalisasi adalah arus informasi yang tidak mengenal batas negara. Secara positif menghasilkan arus informasi semakin terbuka dan persaingan semakin terbuka, baik bagi individu, masyrakat maupun negara. Secara negatif menghasilkan opini yang bisa berkembang secara liar dan dapat mempengaruhi perilaku individu, masyarakat, maupun negara.

Beranjak dari hal tersebut, pemikiran nilai-nilai kegotongroyongan tergeser atau berubah dapat saja terjadi manakala kehidupan bermasyarakat bergeser sesuai dengan perkembangan teknologi. Masyarakat sebagaimana disampaikan oleh Koentjaraningrat (2002:143-144) :

Istilah yang paling lazim dipakai untuk menyebut kesatuan-kesatuan hidup manusia, baik dalam tulisan ilmiah maupun dalam bahasa sehari-hari adalah masyarakat.Dalam bahasa Inggris dipakai istilah society yang berasal dari kata socius, yang berarti "kawan". Istilah masyarakat sendiri berasal dari akar kata Arab yang berbunyi syaraka yang berarti "ikut serta atau berpartisipasi". Masyarakat adalah memang sekumpulan manusia yang saling "bergaul", atau dengan istilah ilmiah, saling "berinteraksi".

Sementara Soerjano Soekanto menegaskan prasyarat Interaksi adalah adanya 
kontak ssial dan komunikasi ${ }^{3}$ Maka bagaimana jika pergeseran tersebut menimbulkan perubahan paradigma interaksi dalam bentuk berbeda. Di dunia maya (cyberspace) misalnya. Dalam pandangan Kropotkin (2006) bahwa gotong royong adalah sebuah faktor utama evolusi. Ia menegaskan : Tetapi bukanlah cinta dan bahkan bukan simpati yang melandasi adanya Masyarakat dalam kehidupan manusia. Yag melandasinya ialah kesadaran meski hanya dalam tahap naluri- akan adanya solidaritas manusiawi. Yang mendasarinya ialah pengakuan nirsadar akan kekuatan yang dipinjam oleh setiap insan dari praktik gotong royong. (hal: xxvi)

Pernyataan ini menegaskan bahwa kegotongroyongan dimaknai sebagai sebuah aktifitas naluriah manusia. Oleh karenanya gotong royong tetap aktual dalam periodisasi manusia kapanpun manusia berkehidupan.

Sebagai sebuah asumsi, gotong royong berubah wujud dapat saja terjadi. Namun apakah menjadi hilang nilai-nilai kegotong royongannya. Sebab bagi bangsa Indonesia gotong royong tidak hanya berbicara tentang perilaku, tetapi juga berperan sebagai nilainilai moral. Berikutnya nilai moral yang ada saat ini apakah menghilangkan nilai-nilai kegotong royongan manakala era sosial media gencar menghinggapi perikehidupan masyarakat.

Terutama ketika melihat ciri masyarakat perkotaan yang lebih individualis namun mudah menerima pengetahuan baru. Sekedar melakukan aktifitas kerja bakti pun bukan pekerjaan yang mudah dilaksanakan oleh masyarakat yang tinggal di perkotaan. Vikar dalam makalahnya mengungkap

Meskipun gotong royong pada awalnya muncul dalam masyarakat perdesaan untuk menunjang kegiatan pertanian, namun implementasinya telah

\footnotetext{
${ }^{3}$ Soerjono Soekanto. Sosiologi suatu pengantar. PT Rajawali Pers : Jakarta, 2012. Hlm. 55
}

memasuki ranah yang lebih tinggi dan luas, dilaksanakan oleh masyarakat di perkotaan bahkan menjadi salah satu nilai utama dalam mewujudkan pembangunan nasional. Akan tetapi, dewasa ini kegotongroyongan mengalami pergeseran dan degradasi nilai. Perilaku gotong royong sudah semakin jarang dilakukan dan susah kita temukan, terutama di wilayahwilayah perkotaan.

Kondisi ini disebabkan karena zaman yang sudah berubah yang menuntut setiap orang sibuk dengan urusan individu yang sangat padat karena tuntutan modal/kapital. Kehidupan masyarakat yang modern dan sangat kompleks ini berdampak pada tidak ditemukannya waktu yang tepat untuk ikut bergabung dalam kegiatan gotong royong dan umumnya teralihkan dengan uang sebagai penggantinya ${ }^{4}$

Di sisi lain, tingkat kepedulian sosial masyarakat melalui media online menjadi peluang bagi pemilik situs crowdfunding atau situs penyedia jasa perantara dalam penggalngan dana di Indonesia. Proses metamorfosis gotong royong inilah yang menjadi fokus tulisan ini ketika memandang konsep gotong royong di tengah arus globalisasi dunia dalam bentuk sosial media dengan melihat sudut pandang teori konstruksi sosial.

\section{Tinjauan Konseptual; Gotong Royong, Perubahan Sosial, dan Konstruksi Sosial}

Sebelum memaparkan proses metamorfosis gotong royong dalam pandangan teori konstruksi sosial, bagian ini akan menjelaskan pengertian dari ketiga konsep tersebut.

\footnotetext{
4 Fikar Damai Setia Gea .2016. Makalah. Crowdfunding: Gerakan Baru Kegotongroyongan Di Indonesia (Tinjauan Evolusi Gerakan Aksi Kolektif Dalam Media Baru)
} 


\section{Tinjauan Konseptual tentang Gotong Royong}

Kata gotong royong berasal dari bahasa Jawa, yaitu Gotong dan Royong. Gotong artinya pikul atau angkat. Royong artinya bersama-sama. Jadi gotong royong dalam arti harfiahnya adalah mengangkat beban secara bersama-sama agar beban menjadi ringan.

Koentjaraningrat (1987) membagi dua jenis gotong royong yang dikenal oleh masyarakat Indonesia; gotong royong tolong menolong dan gotong royong kerja bakti. Kegiatan gotong royong tolong menolong terjadi pada aktivitas pertanian, kegiatan sekitar rumah tangga, kegiatan pesta, kegiatan perayaan, dan pada peristiwa bencana atau kematian. Sedangkan kegiatan gotong royong kerja bakti biasanya dilakukan untuk mengerjakan sesuatu hal yang ifatnya untuk kepentingan umum, yang dibedakan antara gotong royong atas inisiatif warga dengan gotong royong yang dipaksakan.

Lebih lanjut Koentjaraningrat memaparkan jenis-jenis gotong royong yang ada di pedesaan yaitu :

1. Tolong-menolong dalam aktivitas pertanian.

2. Tolong-menolong dalam aktivitasaktivitas sekitar rumah tangga.

3. Tolong-menolong dalam aktivitas persiapan pesta dan upacara.

4. Tolong-menolong dalam peristiwa kecelakaan, bencana dan kematian

Konsep gotong royong juga dapat dimaknai dalam konteks pemberdayaan masyarakat (Pranadji, 2009: 62), karena bisa menjadi modal sosial untuk membentuk kekuatan kelembagaan di tingkat komunitas, masyarakat negara serta masyarakat lintas bangsa dan negara Indonesia dalam mewujudkan kesejahteraan. Hal tersebut juga dikarenakan di dalam gotong royong terkandung makna collective action to struggle, self governing, common goal, dan sovereignty.

Dalam pandangan Kropotkin tentang gotong royong pada masyarakat modern mengungkap bahwa :
Kecenderungan gotong royong dalam diri manusia memiliki asal usul di masa lalu yang sangat jauh. Kecenderungan ini pun terjalin sangat erat dengan semua evolusi umat manusi di masa lalu. Karenanya, kecenderungan ini tetap dipertahankan oleh manusia hingga kini, di luar semua perubahan yang terjadi dalam sejarah, Kecenderungan ini terutama berkembang selama kurun kedamaian dan kemakmuran ( 2006: 81)

Pernyataan Kropotkin tentang gotong royong adalah sebuah keyakinan dirinya bahwa meski terjadi perubahan dalam arena kehidupan manusia, gotong royong tetap ada. Ia mengkritisi ungkapan Herbet Spencer yang mngatakan bahwa Manusia Primitif dalam berperang satu lawan satu ataupun semua adalah hukum kehidupan. Kropotkin memandang gotong royong dibangun melalui sifat jenius kreatif suku liar dan massa separuh liar selama masa awal klan dalam sejarah manusia. Pranata awal ini menimbulkan pengaruh mendalam pada perkembangan lanjut manusia hingga kini.

Tulisan Kropotkin ini menyiratkan betapa pentingnya naluri "saling dukung' yang diwarisi manusia dari perjalanan evolusinya dalam amsyarakat modern kini. Masyarakat modern bersandar pada prinsip' setiap orang untuk dirinya sendiri. Dan negara untuk semua orang'. Tetapi kenyataannya prinsip ini tidak pernah berhasil dan membutuhkan naluri 'saling dukung'

\section{Tinjauan Konseptual Perubahan Sosial}

Konsep Social Change (Perubahan Sosial) memandang bahwa kehidupan manusia tampaknya tidak pernah statis, namun senantiasa mengalami perubahan (baik individu maupun kelompok), dapat berlangsung secara cepat maupun lambat ke arah tujuan yang ingin dicapai. Menurut ahli sosiologi, Mac Iver, terkait dengan "social change"(perubahan sosial) ia berpendapat, "'”. Batasan tersebut menekankan pada perubahan dalam arti keseluruhan yang terdapat pada bangsa atau peradaban. 
Ahli antropologi mempunyai pandangan yang berbeda dengan ahli sosiologi di atas tentang "social change", Pitirin A. Sorokin, berpendapat, "even in technological field the invasion of the cultural element complicates the process of change" . Pandangan ahli antropologi ini menekankan pada proses dalam mempelajari perubahan sosial, sehingga hadirnya teknologi menjadikan perubahan sosial lebih sulit diterangkan secara pasti.

Para ahli sosiologi menekankan perubahan sosial pada "hasil-hasil" perubahan sosial, menyangkut: nilai, aturan, dan sebagai-nya, tidak menekankan pada proses perubahan sosial itu sendiri. Ogburn menjelaskan perubahan sosial sebagai "the great significance of technological developments in producing the rapid social change - that are in values, more, intuitional role and social behavior.Tampaknya, hasil-hasil perubahan sosial dimaksud memiliki titik singgung dengan aspek kebudayaan manusia.

Dalam Wibhawa,

dkk (2010) mengungkap pula definisi perubahan sosial, diantaranya yang dkatakan oleh Brinkerhoff \& White (1985 )yang mengatakan bahwa perubahan sosial sebagai pergeseran terus menerus dalam pola - pola budaya baik materil dan nonmateril.

Pekerja Sosial adalah sebuah profesi yang berfokus pada meningkatkan dan menciptakan keberfulisan sosial, juga memiliki prinsip yang mendasar berupa hak asasi manusia dan keadilan sosial. Seperti yang dikemukakan oleh The International Federation Of Social Workers (IFSW) yang dibenarkan oleh (NASW) dalam Fahrudin (2012 : 61) yaitu sebagai berikut :

The social work profession promotes social change, problem solving in human relationship and the empowerment and liberations of people to enchance well-being. Utilisting theories of human behavior and social system, social work intervenes at the points when people intecart with their environments. Principles of human right and social

\footnotetext{
5 Burhan Bungin, 2007, Sosiologi Komunikasi;
} Teori, Paradigmaa, dan Diskursus Teknologi

\section{justice are fundamental to social work.}

Bertitiktolak hal tersebut, pekerja sosial memandang perubahan sosial adalah hal yang menjadi konsentrasi pada kajiannya. Sebab terjadinya pembangunan berawal dari adanya perubahan sosial. Pembangunan membawa pada dampak positif mupun negatif. Karena perubahan sosial merujuk pada pandangan dinamis dalam kehidupan manusia.

Skidmore and Thackeray (1988) mendefinisikan pekerjaan sosial sebagai berikut:

"...an art, a science, a profession that helps people to solve personal, group (especially family), and community problems and to attain satisfying personal, group, and community relationships through social work practice,," (dalam Wibhawa, dkk, $2010: 41)$

Makna community relationships ini menunjukkan bahwa pekerja sosial berfokus pula pada hubungan antar manusia beserta masalahnya. Karena relasi antar manusia adalah bagian dari kehidupan sosial manusia yang bersifat dinamis.

\section{Tinjauan Konseptual tentang Konstruksi Sosial}

Ritzer (1992) mengungkap secara umum teori dalam paradigmaa sosial memandang manusia sebagai aktor yang kreatif dari realitas sosialnya. Artinya bahwa manusia tidak sepenuhnya ditentukan oleh norma-norma, kebiasaan-kebiasaan, nilai-nilai dan sebagainya, yang kesemuanya itu tercakup dalam fakta sosial yaitu tindakan yang menggambarkan struktur dan pranata sosial. ${ }^{5}$

Menurut pandangan realita sosial, manusia dalam banyak hal memiliki kebebasan untuk bertindak di luar batas kontrol struktur dan pranata sosialnya dimana individu berasal.

Komunikasi di Masyarakat, Kencana Prenada Media Group, Jakarta. 
Manusia secara aktif dan kreatif mengembangkan dirinya melalui responrespon terhadap stimulus dalam dunia kognitif. Karena itu, paradigma definisi sosial lebih tertarik terhadap apa yang ada dalam pemikiran manusia tentang proses sosial, terutama para pengikut interaksi simbolis. Dalam proses sosial, manusia dipandang sebagai pencipta realitas sosial yang relative bebas di dalam dunia sosialnya.

Istilah konstruksi sosial atas realitas (social construction of reality) yang diperkenalkan oleh Peter L.Berger dan Thomas Luckmann (1996), adalah berangkat dari dukungan aliran interaksi simbolis dan fenomenologi Schultz. Berger memusatkan perhatiannya pada proses ketika individu menanggapi kejadian di sekitarnya berdasarkan pengalaman mereka. Dimana beberapa asumsi yang mendasari konstruksi realitas secara sosial adalah sebagai berikut :

a. Realitas tidak hadir dengan sendirinya, tetapi diketahui dan dipahami melalui pengalaman yang dipengaruhi oleh bahasa

b. Realitas dipahami melalui bahasa yang tumbuh dari interaksi sosial pada saat dan tempat tertentu

c. Bagaimana realitas dipahami bergantung pada konvensi-konvensi sosial yang ada

Pemahaman terhadap realitas yang tersusun secara sosial membentuk banyak aspek penting dalam kehidupan, seperti aktivitas berpikir, dan berperilaku. ${ }^{6}$

Kuswarno (2008) mengungkap bahwa konstruksi realitas sosial berhasil menemukan hubungan antara bahasa, interaksi sosial dan kebudayaan. Yaitu bagaimana bahasa merupakan jembatan bagi manusia dalam memahami realitas, sekaligus sebagai pedoman dalam berperilaku.

\footnotetext{
${ }^{6}$ Kuswarno, Engkus. 2008. Etnografi Komunikasi, Suatu Pengantar dan Contoh Penelitiannya.
} Bandung : Widya Padjadjaran. hal 22-24
Berger dan Luckmann menyatakan bahwa institusi masyarakat tercipta dan dipertahankan atau diubah melalui tindakan dan interaksi manusia serta setiap realitas sosial dibentuk dan dikonstruksi oleh manusia. Mereka menyebutkan proses terciptanya konstruksi realitas sosial melalui tiga tahap, yakni eksternalisasi, objektivasi, dan internalisasi. Proses ini terjadi sebagai akibat adanya dialektika antara individu yang menciptakan masyarakat dan masyarakat yang menciptakan individu. Proses dialetika ini terjadi melalui :

a. Eksternalisasi ialah proses penyesuaian diri dengan dunia sosiokultural sebagai produk manusia. Tahap pertama ini merupakan bagian yang penting dan mendasar dalam satu pola interaksi antara individu dengan produk-produk sosial masyarakatnya. Yang dimaksud dalam proses ini ialah ketika suatu produk sosial telah menjadi sebuah bagian penting dalam masyarakat yang setiap saat dibutuhkan oleh individu, maka produk sosial itu menjadi bagian penting dalam kehidupan seseorang untuk melihat dunia luar;

b. Objektivasi ialah tahap di mana interaksi sosial yang terjadi dalam dunia intersubjektif yang dilembagakan atau mengalami proses institusionalisasi. Pada tahap ini, sebuah produk sosial berada proses institusionalisasi, sedangkan individu memanifestasikan diri dalam produk-produk kegiatan manusia yang tersedia, baik bagi produsen-produsennya maupun bagi orang lain sebagai unsur dari dunia bersama. Objektivasi ini bertahan lama sampai melampaui batas tatap muka di mana mereka bisa dipahami secara langsung. Dengan demikian, individu melakukan objektivasi terhadap produk sosial, baik penciptanya maupun individu lain. Kondisi ini berlangsung tanpa harus mereka saling bertemu. Artinya, proses ini 
bisa terjadi melalui penyebaran opini sebuah produk sosial yang berkembang di masyarakat melalui diskursus opini masyarakat tentang produk sosial, dan tanpa harus terjadi tatap muka antarindividu dan pencipta produk sosial;

c. Internalisasi ialah proses di mana individu mengidentifikasikan dirinya dengan lembaga-lembaga sosial atau organisasi sosial tempat individu menjadi anggotanya. Terdapat dua pemahaman dasar dari proses internalisasi secara umum; pertama, bagi pemahaman mengenai 'sesama saya' yaitu pemahaman mengenai individu dan orang lain; kedua, pemahaman mengenai dunia sebagai sesuatu yang maknawi dari kenyataan sosial (Burhan Bungin, 2008:16).

Payne (2016) memandang bahwa arena konstruksi sosial menjadi bagian penting bagi pekerjan sosial. Ia mengatakan bahwa elemen terakhir yang harus dipertimbangkan dalam konstruksi pekerjaan sosial adalah bagaimana politik-politik teori pekerjaaan sosial berlangsung di antara masyarakat. Antar satu arena dengan arena lainnya saling mempengaruhi. ${ }^{7}$

\section{Metamorfosis Gotong Royong dalam Pandangan Teori Konstruksi Sosial}

Beranjak dari ucapan Freidman (2005) bahwa The World Is Flat, ternyata membawa pada konsekuensi perubahan perilaku dalam perikehidupan manusia. Kehidupan tanpa mengenal ruang dan waktu memungkinkan individu menggapai keinginan secara mudah dan cepat. Demikian pula halnya dengan cara berkomunikasi. Komunikasi tatap muka yang seakan menjadi keharusan jika melihat prasyarat interaksi soial, tergantikan dengan teknologi modern.

Sisi positifnya adalah, segala informasi dengan segera dapat diketahui. Potensi 'ketersegeraan' info aktual menjadi potensi baik, ketika menyangkut masalah yang harus segera tertangani. Misal peristiwa bencana alam yang terjadi di Kota Pide DI Aceh. Pada

\footnotetext{
${ }^{7}$ Payne, Malcom. 2016. Teori Pekerjaan Sosial Modern. Edisi ke 4, BPSW Indonesia. DI Yogyakarta. Penerbit Samudra Biru.
}

hari Rabu, 7 Desember 2016). Gempa berkekuatan 6,4 skala richter (SR) yang meluluhlantakkan Kabupaten Pidie Jaya dan sekitarnya di Aceh mendapat perhatian luas dari masyarakat Indonesia bahkan diliput pula oleh media asing, Terlepas dari masalah bencana alam, menariknya adalah sesegera itu infomasi didapatkan, sesegera itu pula penggalangan dana dilakukan dan secepat itu pula dana diraih dari masyarakat.

$$
\text { Melihat Situs Crowdfunding }
$$

Kitabisa.com ${ }^{8}$ dengan proyek sosial yang digagas oleh PKPU Human Initiative berjudul "Gempa Bumi Guncang Banda Aceh - Pidie Jaya, terhitung sejak artikel ini dbuat (tanggal 19 Desember 2016), telah terkumpul dana sebesar Rp. 884.494.716,-. Sebuah dana yang terkumpul cepat dan besar.

Sebagai salah satu ilustrasi, ini membuktikan bahwa potensi masyarakat untuk menyumbang tersebut cukup besar. Artinya banyak masyarakat dengan mudahnya peduli terhadap nasib masyarakat lainnya. Alih-alih perkembangan teknologi terutama sosial media membawa individu tidak peduli terhadap lingkungan sekitar, bahkan membawa pada asumsi lunturnya nilai-nilai kegotongroyongan, ternyata mereka mudah pula tergerak untuk membantu masyarakat yang dirasa kurang beruntung. Fakta tersebut menguatkan pernyataan Friedman (2005) bahwa tindakan gotongroyong berasal dari simpati pribadi atau sosial. Atau dengan kata lain semangat gotong royong masih ada.

Mengutip kata Alfatih Timur (Founder Kitabisa.com)"Saya percaya yang dikatakan Bung Hatta, fondasi Indonesia adalah gotong royong. Kitabisa.com menerjemahkan semangat itu. Di kitabisa.com, kami percaya ada banyak orang baik di Indonesia. Mereka hanya perlu dihubungkan satu sama lain," Ia mencoba dan mengajak masyarakat Indonesia untuk melakukan kebaikan bergotongroyong dengan cara yang berbeda. Ia mengangkat isu gotong royong yang telah ada sejak jaman dahulu kala di Indonesia, bahkan ia mengutip

\footnotetext{
${ }^{8}$ https://kitabisa.com/gempaaceh. Diunduh pada tanggal 19 desember 2016 pukul 23.47
} 
pula ucapan Bung Hatta, mensadarkan kita akan adanya nilai gotong royong yang tetap terpelihara,

Mengupas kembali pemahaman konstruksi sosial Konsep konstruksi sosial diperkenalkan awal oleh Peter L. Berger dan Thomas Luckman dengan bukunya yang berjudul "The Social In Construction of Reality, a Treatise in the Sociological of Knowledge" (1966). Mereka menggambarkan proses sosial melalui tindakan dan interaksinya, dimana individu menciptakan secara terus menerus suatu realitas yang dimiliki dan dialami bersama secara subjektif. Realitas sosial berupa pengetahuan yang bersifat keseharian seperti konsep, kesadaran umum dan wacana publik merupakan hasil konstruksi sosial. Kenyataan itu sendiri bersifat plural, dinamis dan dialektis. Singkatnya bahwa realita atas sesuatu dari seseorang mungkin tidak akan sama dengan realita orang lain.

Walaupun Berger berangkat dari pemikiran Schutz, Berger jauh keluar dari fenomenologi Schutz -yang hanya berkutat pada makna dan sosialitas. Namun demikian, Berger tetap menekuni makna, tapi dalam skala yang lebih luas, dan menggunakan studi sosiologi pengetahuan. Dalam studi ini, Berger juga memperhatikan makna tingkat kedua, yakni legitimasi. Legitimasi adalah pengetahuan yang diobyektivasi secara sosial yang bertindak untuk menjelaskan dan membenarkan tatanan sosial (Berger, 1991: 36). Legitimasi merupakan obyektivasi makna tingkat kedua, dan merupakan pengetahuan yang berdimensi kognitif dan normatif karena tidak hanya menyangkut penjelasan tetapi juga nilai-nilai moral. Legitimasi, dalam pengertian fundamental, memberitakan apa yang seharusnya ada/terjadi dan mengapa terjadi.

Berger lebih memfokuskan pada proses ketika individu menanggapi kejadian di sekitarnya berdasarkan pengalaman mereka, dan itulah yang disebut dengan konstruksi realitas secara sosial. Dalam pandangan konstruksionisme sosial, realitas lebih berbicara tentang apa yang kita katakan saat itu. Artinya bahwa jika kita mengatakan berbeda maka akan berbeda. Sehingga dalam acuan Peter L. Berger dan Thomas Luckmann (1990) penelitian makna melalui sosiologi pengetahuan, mensyaratkan penekunan pada "realitas" dan "pengetahuan". Dua istilah inilah yang menjadi istilah kunci teori konstruksi sosial "Kenyataan" adalah suatu kualitas yang terdapat dalam fenomenafenomena yang memiliki keberadaan (being) yang tidak tergantung kepada kehendak individu manusia (yang kita tidak dapat meniadakannya dengan angan-angan. "Pengetahuan" adalah kepastian bahwa fenomena-fenomena itu nyata (real) dan memiliki karakteristik-karakteristik yang spesifik.

Berdasarkan teori konstruksi sosial tersebut gotong royong dapat dianalisa berdasarkan tiga tahap proses dialektika dalam realita sosial sebagai berikut.

- Eksternalisasi

Eksternalisasi adalah usaha pengekspresian diri yang dilakukan oleh individu ke dalam dunia, berupa kegiatankegiatan mental maupun kegiatan-kegiatan fisik. Proses ini merupakan bentuk ekspresi diri untuk menguatkan keberadaan individu dalam masyarakat. Ketika suatu produk sosial telah menjadi sebuah bagian penting dalam masyarakat yang setiap saat dibutuhkan oleh individu, maka produk sosial itu menjadi bagian penting dalam kehidupan seseorang untuk melihat dunia luar. Seperti halnya ketika nilainilai gotong royong adalah milik masyarakat pedesaan, milik masyarakat yang hubungan kekeerabatannya masih terpelihara, seolah diasumsikan terdegradasikan nilainya di masa modern ini. Mengangkat nilai gotong royong yang sesungguhnya tidak ada prasyarat bertemu fisik interaktif, terkesan masih dianggap belum membangun keterwakilan atas definisi gotog royong. Proses metamorfosis gotong royong dalam tahap eksternalisasi mencoba meredefinisikan kembali bahwa nilai luhur gotong royong dapat dilakukan dengan cara yang berbeda. Seperti yang dilakukan oleh Kitabisa.com yang mengusung pemahaman gotong royong melalui aktifitas crowdfundingnya.

- Objektivasi

Adalah interaksi sosial dalam dunia intersubjektif yang dilembagakan atau 
mengalami institusionalisasi. "Society is an objective reality". Pada tahap ini, sebuah produk sosial berada proses institusionalisasi, sedangkan individu memanifestasikan diri dalam produk-produk kegiatan manusia yang tersedia, baik bagi produsen-produsennya maupun bagi orang lain sebagai unsur dari dunia bersama. Objektivasi ini bertahan lama sampai melampaui batas tatap muka di mana mereka bisa dipahami secara langsung. Objektivasi itu bisa terjadi melalui penyebaran opini sebuah produk sosial yang berkembang dimasyarakat melalui diskursus opini masyarakat tentang produk sosial, dan tanpa harus terjadi tatap muka antara individu dan pencipta produk sosial itu. (Bungin, 2008:16)

Mengutip pandangan gotong royong akan selalu ada dalam peradaban manusia, selaras dengan hal itu pula proses rethinking dan rebranding semkin perlu diwacanakan secara terus menerus. Hingga masyarakat memahami bahwa gotong royong tidak hanya sekedar aktifitas fisik, namun lebih pada solidaritas manusiawi (Kropotkin,2006). Menjadi wajar pula jika para crowdfounder yang diwakili ekspresi katanya oleh Alfatih Timur seorang founder Kitabisa.com, mengungkap bahwa aktifitas crowdfunding adalah implementasi gotong royong atau dalam rumusannya Crowdfunding = Gotong Royong.

- Internalisasi

Adalah individu mengidentifikasi diri di tengah lembaga-lembaga sosial atau organisasi sosial di mana individu tersebut menjadi anggotanya. Ini terkait dengan proses para donatur mengidentifikasikan dirinya menjadi bagian dari sebuah kelompok yang diyakininya. "Man is a social product" 9 . Karena internalisasi adalah proses yang dialami manusia untuk 'mengambil alih' dunia yang sedang dihuni sesamanya.

Pemaknaan gotong royong tradisonal bisa jadi membawa pada sebuah paradigma baru bagi masyarakat saat ini. Keterbaruan tersebut sesungguhnya bukan hal yang baru, mengingat esensi gotong royong adalah bekerja bersama-sama agar beban menjadi ringan. Keterbaruan gotong royong hanyalah pada cara melakukan aktifitas gotong

9 Basrowi, Sukidin, Metode Penelitian Kualitatif Perspektif Mikro, (Surabaya : Insan Cendekian, 2002).hlm. 206 royongnya. Ini adalah proses kompromi antara keberadaan teknologi modern (dalam hal ini sosial media) dengan dorongan hati untuk peduli terhadap sesama. Kehadiran website penggalangan dana berbasis crowdfunding platform hanyalah salah satu bentuk kegotongroyongan saja. Dimana platform crowdfunding memiliki tiga aktor, yaitu pemilik web site, pemilik proyek sosial, dan donatur. Atas tiga aktor tersebut tentu memiliki peran berbeda, akan tetapi esensi semangatnya adalah sama yaitu kepedulian atas masalah sosial yang dirasakan oleh masyarakat yang kurang beruntung dengan membantu meringankan bebannya.

Proses konstruksi sosial ini pada akhirnya membangun pada realita sosial di masyarakat akan munculnya proses metamorfosis gotong royong tersebut di masa kini tanpa menghilangkan nilainilai kegotongroyongan. Sejatinya gotong royong tersebut untuk meringankan beban individu tetap terpelihara, sejatinya terdapat keinginan masyarakat menciptakan ruang privasi individu namun ingin tetap menumbuhkan kepedulian sosial tetap dapat tersalurkan. Tidak ada prasyarat bergotong royong harus disertai kontak fisik interaktif.

\section{Penutup}

Nilai-nilai gotong royong yang diduga pudar, ternyata masih ada. Terbukti dari adanya aktifts spontanitas yang dilakukan sebagian masyarakat di Indonesia manakala ada masalah yang menimpa di lapisan masyarakat kurang beruntung lainnya. Ini adalah potret potensi kepedulian sosial sebagai implementasi gotong royong.

Jika gotong royong ternyata ada dan telah berubah wujud, maka sewajarnya menjadi potensi baik bagi bangsa Indonesia bahwa gotong royong masih ada. Atas potensi gotong royong ini dapat menjadi modal sosial akan kepercayaan masyarakat Indonesia akan solusi pemecahan masalah yang terjadi di Indonesia.

Untuk sebagian masyarakat Indonesia, potensi kepedulian dan gotong royong, 
menunjukkan potensi besar bagi aktifitas penggalangan dana. Ini yang mendorong tumbuhnya para penyelenggara penggalangan dana melalui situs yang biasa disebut dengan Crowdfunding.

Pada akhirnya bagi para praktisi pekerjaan sosial, mulai dapat mempertimbangkan aktifitas Crowdfunding adalah implementasi kegotongroyongan sebagai alternatif lain dalam penggalangan dana. Mengingat peran pekerja sosial " $a$ s $a$ mediator"

\section{Daftar Pustaka}

Bungin, Burhan. 2007, Sosiologi Komunikasi; Teori, Paradigmaa, dan Diskursus Teknologi Komunikasi di Masyarakat, Kencana Prenada Media Group, Jakarta.

Basrowi, Sukidin, Metode Penelitian Kualitatif Perspektif Mikro, (Surabaya : Insan Cendekian, 2002).

Damai Setia Gea. Fikar.2016. Makalah.

Crowdfunding: Gerakan Baru

Kegotongroyongan Di Indonesia

(Tinjauan Evolusi Gerakan Aksi

Kolektif Dalam Media Baru).

Friedman,Thomas. 2006 The World Is Flat: A Brief History of the Twenty-First Century. Published by Farrar, Straus and Giroux . New York.

Koentjaraningrat. 1983. Ciri-Ciri Kehidupan Masyarakat Pedesaan di Indonesia. Dalam Sajogyo dan Sajogyo, Pudjiwati. Sosiologi Pedesaan. Jilid 1. Yogyakarta : Gadjah Mada University Press.

---------------. 2002. Pengantar Ilmu

Antropologi. PT. Rineka Cipta, Jakarta.

Kropotkin, Peter. 2006. Gotong Royong Kunci

Kesejahteraan Sosial; Tumbangnya

Darwinisme

Sosial.

Piramedia,.Depok.

Kuswarno, Engkus. 2008. Etnografi

Komunikasi, Suatu Pengantar dan

Contoh Penelitiannya. Bandung :

Widya Padjadjaran. hal 22-24
Lawang, Robert M. Z. 1985. Pengantar

Sosiologi. Jakarta: Universitas

Terbuka Depdikbud.

Lawang, Robert, M. Z. 2005. Kapital sosial:

Dalam Perspektif Sosiologi Suatu

Pengantar. Depok: FISIP UI Press

Payne, Malcom. 2016. Teori Pekerjaan Sosial Modern. Edisi ke 4, BPSW Indonesia.

DI Yogyakarta. Penerbit Samudra Biru.

Pranadji, Tri. 2009. Penguatan Kelembagaan Gotong Royong dalam Perspektif SosioBudaya Bangsa. Bogor. Jurnal Forum Penelitian Agro Ekonomi, IPB. Volume 27 No. 1, Juli 2009

Soekanto, Soerjono. 2012. Sosiologi suatu pengantar. PT Rajawali Pers : Jakarta,

Wibawa, Budi, Meilany, \& Santoso. 2010. Dasar-dasar Pekerjaan Sosial. Bandung : Widya Padjadjaran

Sumber lain :

https://kitabisa.com/gempaaceh. Diunduh pada tanggal 19 Desember 2016 pukul 23.47 